\title{
Meningkatkatkan Kecerdasan Spiritual Melalui Bermain Peran Penelitian Tindakan di KB \& TK Bunga Bangsa Islamic School Bekasi
}

\author{
Wahyuni Nadar \\ STKIP Kusuma Negara Jakarta \\ Email:wahyudinadar@stkipkusumanegara.co.id
}

\begin{abstract}
In general, the purpose of this study is to obtain data about the spiritual intelligence of children aged 5-6 years in the center of al Islam $K B \& T K$ Bunga Bangsa Islamic School through role play. This research was conducted at KB \& TK Bunga Bangsa Islamic School Bekasi which is located on Jl. Kh. Agus Salim Number 206, Kelurahan Margahayu, District of East Bekasi, Kota Bekasi, West Java Province. Specifically this research will see how big role play can improve every aspect that exist in spiritual intelligence for children aged 5-6 years at KB \& TK Bunga Bangsa Islamic School Bekasi. This research was conducted in second semester of academic year 2016/2017. This action study was conducted using a cycle model from Stephen Kemmis and Mc Taggart. Action research is carried out through planning, implementation, observation and reflection. This research was conducted in two cycles and started with pre-research activities. The average praintervensi result is 57\%, in cycle 1 the result is $65,5 \%$ and cycle 2 reaches $80 \%$ on average. From the data there is a significant increase in each cycle. Improvement is seen in every aspect that depicts children's spiritual intelligence such as self-awareness, spontaneity, internally motivated, seeing life from vision and based on fundamental, holistic values, seeing system and universality, compassion (sense of community, sense of following the flow of life) diversity, independent, firm against the majority, fundamentally questioning, rearranging in the big picture, and steadfast in difficulty.Thus, the learning process through the role play to improve spiritual intelligence is




\section{Wahyuni Nadar}

said to have been achieved because most of the indicators in the competence of the ability of spiritual intelligence has increased. The implication of this research is that role playing can be one strategy to improve spiritual intelligence.

Key word: Spiritual Intelligence, role play, action research

\section{PENDAHULUAN}

\section{Latar Belakang}

Kecedasan spiritual merupakan salah satu kecerdasan yang dimiliki oleh setiap manusia sebagai mahluk ciptaan Allah SWT. Kecerdasan ini sudah diberikan Allah sejak dalam kandungan. Bahkan Allah telah menganugerahkan kecerdasan spiritual jauh sebelum janin dalam kandungan terbentuk. Hal ini dijelaskan dalam surat Al-A'raf : 172 yang berbunyi: "Apakah engkau bersaksi bahwa Aku ini Tuhanmu. Ya aku bersaksi bahwa Engkau adalah Tuhanku”. Kesaksian ruh manusia ini nenunjukkan kemurnian atau keaslian manusia yang memiliki potensi dasar untuk mengakui dan tunduk akan ke-Maha Kuasaan Allah SWT., Selain potensi dasar tersebut, Allah telah memberikan dua kecenderungan yang bersifat potensial ketika ruh itu dihembuskan pada setiap janin (bayi : menurut sebagian ahli di usia janin 4 bulan), yakni kecenderungan spiritual yang semakin mendekatkan diri dengan Allah SWT (Taqwaha) dan kecederungan spiritual yang menjauhi Allah SWT (Fujuroha). Dua kecenderungan ini digambarkan Allah SWT dalam surat Asy-Syam ayat 7-8, yang berbunyi :

"Dan demi jiwa yang dalam proses penyempurnaan. Maka kami ilhamkan (hembuskan) kecenderungan berbuat fujur dan taqwa").

Berbagai keterangan atau informasi dasar tersebut memberikan gambaran bahwa potensi kecerdasan spiritual telah ditanamkan Allah SWT sejak manusia belum terbentuk sebagai sebuah janin dan setelah menjadi -60 -

Al Marhalah : Jurnal Pendidikan Islam. Volume. 13, No. 1 Mei 2018 
janin Kecerdasan inilah yang membedakan antara manusia dengan mahluk lainnya. Kecerdasan spiritual merupakan bekal setiap manusia berhubungan secara personal dengan Allah SWT.

Perkembangan kecerdasan spiritual setiap manusia tergantung pada lingkungannya. Terlebih lagi jika yang dimaksud adalah anak-anak, maka orang tua dan lingkungan keluargalah yang menjadi dasar pendasi perkembangan spiritualnya. Hal ini telah disampaikan dalam Sabda Rosulullah Muhammad SAW yang mengatakan bahwa "Setiap manusia dilahirkan dalam keadaan fitrah. Maka kedua orang tuanyalah yang dapat mengarahkan atau menjadikannya sebagai seorang Yahudi, Nasrani atau Majusi” (HR Bukhori). Orang tua yang dimaksud dalam konteks hadist tersebut dapat diperluas penafsirannya kepada setiap orang dewasa yang memiliki tanggung jawab terhadap seorang anak. Orang tua yang dimaksud dapat berwujud orang tua kandung, orang tua angkat, nenek atau kakek, paman-bibi, gurunya dan orang dewasa lainnya. Isyarat hadist tersebut sangat jelas bahwa potensi kecerdasan beragama akan berkembang jika lingkungan social (Social Context seperti yang dikemukakan Vygotsky) akan memberikan dampak yang sangat kuat dan besar. Hal tersebut digambarkan pula dalam penelitian yang dilakukan oleh Saggaf S. Pettalongi dalam jurnalnya yang berjudul Islam dan Pendidikan Humanis dalam Resolusi Konflik Sosial mengatakan konflik sosial yang terjadi dalam masyarakat majemuk dapat diresolusi dengan pendidikan humanis . Pendidikan Humanis yang dimaksud yaitu pendidikan yang mengembangkan kecerdasan spiritual sehingga pendidikan dapat memanusiakan manusia, yaitu manusia yang memiliki kriteria sebagai pemimpin yang bijak, arif dan adil. 


\section{Wahyuni Nadar}

Atas dasar pemikiran tersebut, perlu penelusuran konsep dan penerapan cara-cara pengembangan potensi kecerdasan spiritual pada anak sejak usia dini. Dalam penelitian ini, upaya untuk meningkatkan kecerdasan spiritual dilakukan dengan bermain peran.

\section{Hakikat Anak Usia Dini}

Masa usia dini merupakan periode awal yang paling penting dan mendasar dalam sepanjang rentang pertumbuhan serta perkembangan kehidupan manusia. Dilihat dari pengertian perkembangan menurut Santrock yaitu pola gerakan atau perubahan yang dimulai dari pembuahan dan berlanjut sepanjang siklus kehidupan. Akan tetapi diantara rentang kehidupan manusia, masa usia dini merupakan masa yang paling fundamental. Bahkan Hurlock mengatakan masa usia dini merupakan saat yang kritis dalam perkembangan manusia . Pada masa ini ditandai oleh berbagai periode penting yang menjadi fundamen dalam kehidupan anak selanjutnya sampai periode akhir perkembangannya. Salah satu periode yang menjadi penciri masa usia dini adalah the Golden Ages atau periode keemasan. Banyak konsep dan fakta yang ditemukan memberikan penjelasan periode keemasan pada masa usia dini. Beberapa label konsep disandingkan pada masa anak usia dini seperti masa eksplorasi, masa identifikasi/imitasi, masa peka, masa bermain dan masa trozt alter 1 (masa membangkang tahap $1)$.

Label konsep tersebut diperkuat oleh fakta yang ditemukan oleh ahli ahli Neurologi yang menyatakan bahwa pada saat lahir otak bayi mengandung 100 sampai 200 milyar neuron atau sel syaraf yang siap melakukan sambungan antar sel. Seperti yang diakatakan Dr. Keith Osborn, ahli perkembangan anak dari Universitas Georgia, bahwa sekitar $50 \%$ kapasitas kecerdasan manusia telah terjadi ketika usia 4 tahun, $80 \%$ telah terjadi ketika berusia 8 tahun, dan mencapai titik kulminasi $100 \%$ ketika -62 -

Al Marhalah : Jurnal Pendidikan Islam. Volume. 13, No. 1 Mei 2018 
anak berusia 8 sampai 18 tahun. Pertumbuhan fungsional sel-sel syaraf tersebut membutuhkan berbagai situasi pendidikan yang mendukung, baik dalam situasi pendidikan keluarga, masyarakat maupun sekolah. Para ahli pendidikan pun sepakat bahwa jika periode keemasan tersebut hanya berlangsung satu kali sepanjang rentang kehidupan manusia. Hal ini menunjukkan bahwa betapa meruginya suatu keluarga, masyarakat dan bangsa jika mengabaikan masa-masa penting yang berlangsung pada anak usia dini. Seperti teori tabula rasa yang dikemukakan oleh John Lock, dimana teori tabula rasa ini berarti bahwa anak-anak secara lahiriah seperti kertas kosong. Pengalaman yang dialami bersama keluarga dan masyarakatlah yang akan mengisi kertas kosong tersebut.

Mengingat pentingnya masa ini, maka peran stimulasi berupa penyediaan lingkungan yang kondusif harus disiapkan oleh para pendidik, baik orang tua, guru, pengasuh ataupun orang dewasa lain yang ada disekitar anak, sehingga anak memiliki kesempatan untuk mengembangkan seluruh potensinya. Hal tersebut sesuai dengan yang dikatakan oleh Papalia bahwa kognisi dan kepribadian seseorang lebih sering dipengaruhi oleh pengalaman, jenis keluarga, sekolah dan orang-orang yang mereka temui. Hal tersebut menegaskan bahwa setiap anak tidak hanya membawa bakat atau potensi yang telah Tuhan berikan akan tetapi perkembangan setiap anak akan diwarnai oleh faklor eksternal diantanya keluarga dan lingkungan.

\section{Hakikat Kecerdasan Beragama}

Setiap agama memiliki ajaran tentang menanamkan keimanan pada penganutnya dan refleksi keimanan tersebut dicerminkan dalam sikap dan perbuatan. Islam sebagai agama yang sempurna telah memberikan gambaran awal tentang bagaimana proses memulai mengembangkan kecerdasan 


\section{Wahyuni Nadar}

spiritual sejak masa pra-konsepsi sampai ke masa pertumbuhan janin dalam rahim Ibu. Rosulullah memberikan ajaran dan contoh langsung tentang caracara melakukan hubungan suami istri sebagai bentuk pembelajaran untuk mempersiapkan anak yang cerdas beragama pada masa konsepsi janin dan setelah lahir menjadi anak manusia. Diantara ajaran rosulallah adalah berdo'a sebelum persetubuhan suami istri berlangsung. Pada masa terjadinya konsepsi, Rosululllah mengajarkan konsistensi berdo'a sebelum bersetubuh setelah terjadinya janin. Hal tersebut menekankan pembahasan pada bagian sebelumnya bahwa potensi kecerdasan spiritual sudah diberikan jauh sebelum masa kandungan. Ketika dalam kandungan orang tua memberikan penguatan kecerdasan spiritual dengan memberikan makanan yang halal dan lantunan ayat suci al-Quran.

Salah satu bentuk kecerdasan spiritual yaitu rasa ke-Tuhanan yang terlihat dari perkataan dan perbuatan anak. Rasa ke-Tuhanan ini sangat memegang peranan penting dalam diri pribadi anak. Perasaan ketuhanan pada usia ini merupakan fundamen bagi pengembangan perasaan ketuhanan periode berikutnya. Seiring dengan perkembangan kognisi, emosi, dan bahasa anak maka orang tua mejadi lingkungan pertama untuk untuk membantu perkembangan kesadaran beragamanya. Dalam konsepsi lain, Abin Syamsuddin (seperti dikutif Syamsu Yusuf) menggungkapkan kesadaran beragama pada anak usia 2-6 tahun yang ditandai dengan ciri-ciri sebagai berikut :(1) Sikap keagamaannya bersifat reseptif (menerima) meskipun banyak bertanya, (2) Pandangan ketuhanannya bersifat anthropormorph (dipersonifikasikan), (3) Penghayatan secara rohaniah masih superficial (belum mendalam) meskipun mereka telah melakukan atau berpartisipasi dalam berbagai kegiatan ritual, (4) Hal ketuhanan dipahamkan secara ideosyncritic (menurut khayalan pribadinya ) sesuai denga taraf 
berpikirnya yang masih egosentrik (memandang segala sesuatu dari sudut dirinya).

Perkembangan spiritual anak usia dini bibagi menjadi beberapa bagian. Seperti yang disimpulkan dari pendapat Abin Syamsudin dalam Yusuf Samsu tentang tahapan spiritual anak sebagai berikut :

a. 0 - 2 Tahun

Pada usia 0-2 tahun, kecerdasan beragama anak secara umum berada dalam tahap reseptif (menerima) segala bentuk pengetahuan, pengalaman dan berbagai nilai-nilai keagamaan.

b. 2-4 tahun

Kecerdasan beragama anak mulai mengalami perkembangan sejalan dengan luasnya interaksi sosial, perkembangan bahasa dan kognitifnya. Pada usia ini, anak sudah mulai meyakini akan adanya hal-hal yang ghaib (seperti hantu, pocong atau vampire).

c. 4-6 Tahun

Berbagai khayalan tentang Tuhan, Malaikat, Syetan dan hal-hal ghaib lainnya akan diimajinasikan sesuai dengan kadar pengetahuan dan pengalaman keagamaan yang diterima anak. Proses perkembangan kecerdasan beragama seperti ini sekaligus merupakan awal perkembangan munculnya Ikhsan,

d. 6-8 Tahun

Walaupun dominasi masa-masa imitasi, identifikasi dan imajinasi keagamaan masih berlangsung pada usia ini namun pergerakan yang menunjukkan adanya perkembangan kecerdasan beragama secara lebih kompleks sudah mulai tampak. Anak-anak sudah mulai memperdebatkan 


\section{Wahyuni Nadar}

tentang kehebatan Tuhan, Malaikat, keindahan syurga dan buruknya neraka walaupun masih dikuasai oleh berbagai kekuatan khayalan dan imajinasinya. Secara lebih khusus, Zohar mengidentifikasikan sepuluh kriteria mengukur kecerdasan beragama seseorang, yaitu : (a) Kesadaran Diri, (b) Spontanitas, termotivasi secara internal, (c) Melihat kehidupan dari visi dan berdasrkan nilai-nilai fundamental, (d) Holistik, melihat sistem dan universalitas,(e) Kasih sayang (rasa berkomunitas, rasa mengikuti aliran kehidupan), (f) Menghargai keragaman, (g) Mandiri, teguh melawan mayoritas, (h) Mempertanyakan secara mendasar, (i) Menata kembali dalam gambaran besar, (j) Teguh dalam kesulitan.

\section{Hakikat Bermain Peran}

\section{Metode}

Penelitian ini akan dilakukan dengan seting pendidikan KB \& TK Bunga Bangsa Islamic School Bekasi. Seting wilayah ini dipilih dengan mempertimbangkan model pembelajaran sentra yang diterapkan di TK ini. Dengan model sentra yang diterapkan di KB \& TK Bunga Bangsa Islamic School, maka penelitian tentang bidang pengembangan kecerdasan spiritual akan lebih fokus dan terlihat. Peneliti memilih sentra Al- Islam sebagai tempat penelitian karena program sentra Al-Islam sangat sejalan dengan karakteristik perkembangan kecerdasan spiritual. Tempat penelitian yang dipergunakan sangat memungkinkan peneliti untuk membangun berbagai bentuk perbaikan program pendidikan di Bunga Bangsa Islamic School karena memiliki akses pembinaan para guru dan kepala sekolah.

Penelitian ini dilaksanakan dengan menggunakan metode riset aksi (Action Reseach). Metode ini dianggap sesuai dengan tujuan penelitian yang mengarahkan kegiatan penelitian pada upaya mencari prototipe dan strategi dalam meningkatkan kecerdasan beragama pada usia Taman Kanak-kanak. Disamping itu, penelitian lebih menekankan pada proses penelaahan program -66 -

Al Marhalah : Jurnal Pendidikan Islam. Volume. 13, No. 1 Mei 2018 
pembelajaran TK dan bermain peran dalam pengembangan kecerdasan beragama. Proses ini membutuhkan suatu prosedur kerja dengan berbagai tahapan. Hal ini sejalan konsep riset aksi (Action Research) yang dikembangkan oleh Kemmis dan Taggart dalam Jean McNiff yang menggambarkan tahapan prosesnya kedalam empat tahap yaitu 1) perencanaan, 2) tindakan, 3) observasi dan 4) refleksi serta revisi.

\section{Pembahasan}

Proses penelitian yang dilakukan oleh peneliti dan kolaborator (guru sentra al Islam) tentang peningkatan kecerdasan spiritual dengan bermain peran di KB \& TK Bunga Bangsa Islamic School telah memakan waktu kurang lebih dua bulan. Di mulai dengan observasi, meminta ijin, uji instrumen, kemudian dilanjutkan dengan penelitian. Penelitian yang dilakukan telah melalui beberapa tahap yaitu pra intervensi, siklus 1 dan siklus 2. Berikut hasil analisa data yang dilakukan di setiap siklus.

Sebelum peneliti melakukan siklus 1 , peneliti melakukan persiapan untuk melakukan pra intervensi yaitu mengumpulkan data-data anak yang akan diteliti melalui observasi langsung dan melakukan pretest untuk mengetahui kondisi awak anak. Setelah menyiapkan responden, maka peneliti dengan guru sentra sebagai kolaboator menyiapkan instrumen untuk mengambil data pra intervensi. Pada proses pra intervensi, peneliti melihat laporan perkembangan perbulan anak yang dinamakan grafik perkembangan anak (GPA). Dari data tabel hasil pra intervensi di atas maka dapat terlihat bahwa kecerdasan spiritual anak masih rendah. Hal tersebut dapat dilihat dari 13 anak yang ada dalam satu kelas terdapat 12 anak yang masih di bawah standar target pencapaian yaitu $71 \%$. Prosentase rata-rata yang diperoleh 


\section{Wahyuni Nadar}

pada pra intervensi yaitu $57 \%$. Untuk itu peneliti dan guru sentra sebagai kolaborator akan melakukan tindakan pada siklus 1 .

Setelah dilakukan observasi pada siklus 1, ternyata terdapat 9 anak yang belum mencapai $71 \%$ sesuai dengan target pencapaian yang diharapkan dan 1 anak yang tidak mengalami peningkatan. Rata-rata pencapaian pada siklus 1 hanya 65.5\%. Berdasarkan hasil di siklus 1, kemampuan mempertanyakan secara mendasar seperti mempertanyakan keberadaan Allah, malaikat dan nabi masih rendah. Begitu juga dengan menata kembali dalam gambaran besar seperti memberikan argumentasi sifat-sifat Allah masih rendah. Dengan demikian peneliti bersama kolaborator akan meneruskan kembali tindakan ke siklus 2 dengan harapan akan terjadi peningkatan sesuai dengan target yang diharapkan.

Melihat hasil pada siklus 2, maka dapat diakatakan tercapai sudah target yang diharapkan dalam penelitian ini. Peningkatan yang diperlihatkan dalam setiap indikator yang ada dalam instrumen di setiap siklus merupakan gambaran keberhasilan bermain peran dalam meningkatkan kecerdasan spiritual anak kelompok B di KB \& TK Bunga Bangsa Islamic School. Seperti yang telah dikatakan pada bab 2, bahwa target pencapaian keberhasilan dalam penelitian ini yaitu $71 \%$. Sedangkan hasil rata-rata kelas pada siklus 2 telah mencapai 79, 68. Dengan demikian maka siklus dihentikan.

Pada saat peneliti merancang kegiatan untuk di siklus 2 dengan melibatkan guru dalam bermain peran. Membangun interaksi yang aktif dan memberikan kesempatan pada anak untuk bereksplorasi akan membantu anak-anak untuk mengembangkan potensinya. Selain itu, dengan keikutsertaan guru dalam kegiatan bermain peran akan memotivasi anak-anak dalam berekspresi dan lebih menyelami peran yang dimainkan sehingga dapat menangkap makna dari kegiatan bermain peran tersebut. Dengan -68 -

Al Marhalah : Jurnal Pendidikan Islam. Volume. 13, No. 1 Mei 2018 
demikian, anak-anak pun sudah lebih aktif an percaya diri dalam memberikan pendapat. Di siklus 2 ini terlihat peningkatan yang berarti yaitu dengan ratarata $80 \%$. Dengan perincian semua anak (10 anak) mengalami peningkatan. Melihat data pada setiap siklus, maka dapat dikatakan bahwa bermain peran dapat meningkatkan kecerdasan spiritual anak usia 5-6 tahun. Dalam penelitian ini, peneliti menemukan analisis bahwa bermain peran dapat memberikan situasi pembelajaran yang menyenangkan dan dapat meningkatkan kecerdasan spiritual. Banyak aspek lain yang akan berkembang salah satunya kecerdasan Bahasa dan sosial.

Berdasarkan hasil penelitian diatas, kecerdasan spiritual pada anak usia 5-6 tahun akan terjadi peningkatan apabila menggunakan aktivitas yang tepat. Peneliti memilih bermain peran bermain peran sangat menarik minat anak-anak untuk bisa merasakan dan berekspresi sesuai dengan kondisi yang dimunculkan. Bermain peran sesuai dengan tahapan pembelajaran anak usia dini yang aktif, memenuhi rasa ingiin tahunya yang besar dan menyenangkan. Bermain peran membuat anak aktif melakukan (learning by doing).

\section{KESIMPULAN}

Selama proses penelitian berlangsung ada beberapa hal yang menjadi catatan peneliti. Salah satunya faktor yang menyebabkan kecerdasan spiritual anak kelompok B (usia 5-6 tahun) di KB \& TK Bunga Bangsa Islamic School Bekasi masih rendah yaitu penilaian kecerdasan spiritual masih dilihat dari hasil belajar yang bersifat akademik, seperti hapalan surat alQuran (juz 30), hadist, bacaan doa dan bacaan sholat. Sedangkan yang dimaksudkan kecerdasan spiritual tidak hanya itu tetapi lebih pada pemahaman yang diaplikasikan dalam sikap keberagamaan. 


\section{Wahyuni Nadar}

Pada siklus 1 mencapai hasil yang diharapkan. Pada siklus 1, pertemuan pertama masih ditemui kesulitan oleh guru. Khususnya ketika mengarahkan anak untuk mengemukakan pendapat maupun menjawab pertanyaan. Situasi pada pertemuan pertama masih cenderung pasif dan hanya beberapa anak yang terlihat menonjol. Hal tersebut dikarenakan materi pada siklus 1 yang membahas tentang api. Guru agak kesulitan memasukan butir instrument ke dalam proses pembelajaran, sehingga ada beberapa butir instrumen yang terlihat agak dipaksakan masuk dalam materi.

Pada siklus 2, peneliti mengubah pola pembelajaran walaupun dengan kegiatan yang sama yaitu bermain peran. Peneliti mencoba bermain peran dengan mengikutsertakan guru sebagai salah satu tokoh. Hal tersebut untuk lebih memotivasi anak dalam berekspresi memerankan tokoh yang ada. Hal tersebut terlihat ketika anak-anak berinteraksi lebih ekspresif dengan tokoh yang lain diantaranya yaitu bu guru. Anak-anak secara langsung melihat guru yang mencontohkan bagaimana caranya memerankan tokoh. Dengan demikian anak-anak lebih menyelami tokoh yang diperankan dan menyelami cerita.Sehingga ketika di akhir kegiatan (evaluasi) anak-anak dapat menjawab pertanyaan yang dilontarkan guru. Berdasarkan hasil penelitian secara kualitatif, terlihat adanya peningkatan kecerdasan spiritual melalui bermain peran.

\section{Daftar Pustaka}

Anam, Saiful. 2007. Jangan Remehkan Taman Kanak-kanak: Taman Yang Paling Indah. Solo: Wajatri.

Dahlan, MD. 1990, Model-model Mengajar, Bandung; Diponogoro.

Darajat, Zakiyah. 2001. Metodologi Pengajaran Agama Islam. Jakarta: Bumi Aksara. 
Desmita, 2009. Psikologi Perkembangan Peserta Didik, Bandung : Rosdakarya.

Djiwandono dan Wuryani, Sri Esti, Psikologi Perkembangan Anak, Jakarta : Grasindo

Elliott, John. 1991. Action Researchfor Educatonal Change, Philadephia: Open

Hapidin.2006. Strategi Pembelajaran. Bekasi: Pusdaini Press STAI Bani Saleh.

Hurlock, Elizabeth, 1997, Perkembangan Anak, Jakarta : PT. Gelora Aksara Pratama

Ikhsan, Fungsi Tujuan dan Jenis PAUD, 2010, (http://tunas63.wordpress.com/2010/06/15/fungsi-tujuan-dan-jenispaud/)

Jalaluddin. 2005. Psikologi Agama. Jakarta: RajaGrafindo Persada.

Joyce, B., Marsha, W., \& Calhoun, E., 2009, Models of Teaching, Yogyakarta : Pustaka Pelajar.

McNiff, Jean.1992. Action Research. Principles and practice. New York : McMillan Educations Ltd.

Monks, F.J., 2002. Psikologi Perkembangan, Yogyakarta : Gadjah Mada University Press.

Nursisto. 2000. Kiat Menggali Kreativitas. Semarang: Mitra Gama Media Algesindo

Papalia, Diane E., 2008, Human Development, Terjemahan A.K. Anwar, Jakarta: Kencana 


\section{Wahyuni Nadar}

Pettalongi, Saggaf S. Islam dan Pendidikan Humanis dalam Resolusi Konflik Sosial, (https://journal.uny.ac.id/index.php/cp/article/view/1474/pdf. 2013). no.2

Roestiyah, 20011, Strategi Belajar Mengajar, Jakarta : Rineka Cipta.

Santrock, J.W, 2002. Life Spain Development, terjemahan Achmad Husairi dan Juda Damanik, Jakarta : Erlangga

Satibi, Otib. 2005. Metode Pengembangan Moral dan NIlai-Nilai Agama. Jakarta: Pusat Penelitian Universitas Terbuka.

Sholehuddin, Konsep Dasar Pendidikan Pra Sekolah, (Bandung : FIP UPI, 2000), h.11

Sudjana, Nana. 1989. Cara Belajar Siswa Aktif dalam Proses Belajar Mengajar. Bandung: Sinar

World Book Group. 1995. The Human Body. Chicago : World Book, Inc.

Yusuf, Syamsu. 2002. Psikologi Perkembangan Anak dan Remaja. Bandung: Remaja Rosdakarya.

Zohar, Danah, dan Marshall, Ian.2001. SQ: Memanfaatkan Kecerdasan SpiritualDalam Berfikir Integralistik Dan Holistik Untuk Memaknai Kehidupan, Jakarta: Pustaka Mizan. 